\title{
Work-Life Balance Constructs and Job Satisfaction: Evidence from the Palestinian Investment Sector
}

\author{
Muna M. Khoury ${ }^{1}$ \\ ${ }^{1}$ Doctoral Candidate, Antwerp University, Birzeit University, Palestine \\ Correspondence: Muna M. Khoury, Doctoral Candidate, Antwerp University, Birzeit University, Palestine.
}

Received: December 4, 2020

Accepted: January 5, 2021

Online Published: January 8, 2021

doi:10.5539/ibr.v14n2p13

URL: https://doi.org/10.5539/ibr.v14n2p13

\begin{abstract}
With the continuous evolution of globalization and the increasing technological openness between all countries worldwide, employees' awareness about the quality of life and balance between work and life matters has constantly been escalating. Although a tremendous body of literature internationally exists on Work-Life Balance and Job Satisfaction, yet previous scholars across the Palestinian context have not connectedly addressed these terms. Both Work-Life Balance and Job satisfaction matters have been recently getting more focus than expected due to the fast-forwarding life cycles and the continuous obnoxious and inferior political and economic situation that faces every person, family, society, and company in Palestine, which have a significant influence on the productivity and performance of both the Palestinian organizations and employees. The focus of this study is on the measurement of work-life balance and job satisfaction of employees and the exploration of the relationship between both terms at different Palestinian companies in the investment sector while exploring the critical working issues and personal life matters among employees with further examination on how the concept of WLB might affect job satisfaction. This study's key contribution is to highlight this relationship among the Palestinian organizations and thus be further addressed and considered across all Palestine and in other developing countries with similar political and economic threats, especially after having this relationship positively correlated by the current research results.

The study was conducted on 502 employees from 7 different investment companies in Palestine. The statistical tests that were processed and the interference relationships tested confirmed a positive relationship between the three constructs of Work-Life Balance and Job Satisfaction.
\end{abstract}

Keywords: work-life balance, work/family conflict, job satisfaction, work-life balance scale, job satisfaction scale

\section{JEL Classification: M12, M19}

\section{Introduction}

Work-Life Balance is considered one of the most urgent topics that need research to be carried on, as the concept's details exhibit the main issues affecting employees' performance. Work-Life Balance (WLB) is a state of well-being that any person should achieve if he/she could reach a balance between family, friends, and work responsibilities. All workers should have a right to practice careers that do not hinder their ways of finalizing their personal-life matters. Many people do not even recognize that they are in a state of imbalance and look to balance their work-life schedules.

The relationship between work and family life is connected, and each has a direct effect on the other one. This implies that, work responsibilities can affect workers' personal life, and personal life matters can also affect people's work responsibilities (Hill, Hawkins, Ferris, \& Weitzman, 2001; Kuzulu et al,2013, Weiss, 2002; Munn, 2013; Peeters, Montogomery, Baker, \& Schaufeli, 2005). The term WLB reveals the view that both personal life and work can be viewed as complementary, rather than competing, components of life (Holliday \& Manfredi, 2004; Lewis, 2000). The balance between work and life matters can be attained visualizing the concept of WLB as a two-way operation that contemplate both employee's and employer's needs (Lewis, 2000).

This study seeks to answer several issues concerning the effect of WLB on employee's job satisfaction at the selected companies as the study/research population. Therefore, several questions are built up, forming the basis for this research; these questions are as follows: 
1- What type of relationship exists between job satisfaction and the three components of work-life balance (WLB); work interference with personal life (WIPL), personal life interference with work (PLIW), and work personal life enrichment (WPLE)?

2- Do the employees at the representative companies struggle in reconciling work with life commitments?

3- What WLB programs would enable the employees to achieve an improved status of work-life balance?

Although work-life balance is a well-known term in Western countries and organizations, there have been no studies on Palestine. Therefore, there is a list of reasons behind the desperate need to administrate the concept of work-life balance and programs in any organization in Palestine. The current political situation by which the Palestinian territories face the Israeli occupation is one major reason why Palestinian companies need to adopt Work-life Balance in their work environment. Another fact is the current continuously challenging economic situation, which loads both the Palestinian employees and employers with stress to balance their various responsibilities. Coping with these current continuous political and economic situations burdens the companies to seek how to get the maximum performance out of their employees while being challenged to maintain the regular working routine. Thus eventually, adapting work-life balance policies that shall bring benefits for all employees regardless of their managerial positions.

\section{Literature Review}

\subsection{Work-Life Balance}

The beginnings of the work-life balance phenomenon began in the late 1970s. The purpose was to describe the balance between personal life and work-life of working homemakers that are home and wish to go back to work. (Families Working, 2009). "Since then, work-life balance practices have been studied across disciplines including economics, gender studies, information systems, management, social psychology, and sociology" (Beauregard \& Henry, 2009). Work-Life Balance has been initially studied in the "nineteenth century when workers and unions successfully campaigned against long working hours in factories, and it became apparent that a decrease in working hours had no significant impact on production (Bosworth and Hogarth, 2009). During the twentieth century," many studies (e.g., Mayers, 1924) took place on the WLB concept, which resulted in emphasizing the role of human relations and the effect of reducing the working hours on workers' output. "In 1938, the U.S. government introduced the Fair Labor Standards Act with a maximum workload of 44 hours per week" (U.S. Department of Labor, 2013). Later, "in the 1980s, companies began to introduce family-friendly policies, such as flexible work schedules and telecommuting". Such policies were initially concerned with working women but eventually "they accommodated women's and men's needs. "The current notion of WLB gained currency, with a view to protecting family life in an increasingly competitive workplace and career-driven society" (Parakati, 2010). In the last few years, it has been highlighted in many studies that social, economic, and cultural changes impact the flow of the working day of the people. "The rise in the living standards and the importance of work and family life have intensified the demands on individuals, on work, and on family" (Chandra, 2012; Darcy, McCartthy, Hill, \& Grady, 2012; Kuzulu, Kurtuldu, \& Ozkan, 2013; and Pattusamy \& Jacob, 2016).

"Formal definitions of the term work-life balance vary but generally converge around the idea that this balance is not about the equivalent distribution of time between professional and personal activities, but rather general satisfaction with one's life" (Berry, 2010). However, Felstead, Jewson, Phizacklea, and Walters (2002), defined work-life balance in their work as "the relationship between institutional and cultural times and spaces of work and non-work in societies where income is predominantly generated and distributed through labor markets." Whereas the sociologists Estes and Michael (2005) argued that a single definition of work-life balance does not exist and no such definition that would accumulate agreement of many parties exist. Nevertheless, they "suggested that work-life balance practices refer to one of the following: organizational support for dependent care, flexible work options, and family or personal leave." "Work-life balance is a concept that deals with the ability of individuals, irrespective of the age or their gender, to get 'into a flow' that allows them to combine the demands of work and other non-work responsibilities and activities" (Hughes and Bonzionelos, 2007).

The concept of Work/life Balance contains many parts, including the period along which people work, the timeframe in which they work, and their location (Glynn et al., 2002). These aspects are translated in a range of work policies and procedures, e.g., flexible working hours, part-time working, working from home, compressed workweeks, temporary working, teleworking, career breaks, and annualized hours (Maxwell and McDougall, 2004).

"In Practice, WLB involves adjusting work patterns so that everyone, regardless of age, race, or gender can find 
a rhythm that enables them more easily to combine work and their other responsibilities and aspirations" (Pillinger, 2001:1).

Nowadays, WLB is considered a significant matter for both employers and employees that they need to tackle. It is even evident that many of the workplace challenges are believed to be a result of unbalanced work-family matters. "(Berg, Kalleberg, and Appelbaum, 2003) in his article had mentioned that job attributes, organizational culture, and its pertaining environment and employee-friendly policies have a positive and progressive influence on individual WLB".

\subsection{WLB Policies/Practices}

Research across the years have shown numerous work-life balance flexible working schedules, practices, policies, programs work arrangements concerning leave breaks, parenting and pregnancy, and additional work provisions .

"Work-life balance policies help employees in managing their work and family in a better way and enhance their attitudes and behaviors such as organizational attachment (Groover and Croocker, 1995), Job Satisfaction (Kossek and Ozeki, 1998) and intention to stay (Kossek, \& Lobel, (1996).". Dockel (2003), "declared that work-life policies have a strong and significant relationship with organizational commitment." Lockwood (2003), in his work, highlighted that senior management has a vital role in managing and designing work-life balance practices. These practices increase workers' motivation, and thus their performance will increase across time. Concerning Eisenberger et al. (1986) Perceived Organizational Support Theory, when employees at the workplace acknowledge their employer's attention and care, support in satisfying their employees' personal needs and the admiration to their values; the employees in return shall show higher commitment levels and satisfaction at the workplace. Emphasizing that the more engaged workers are at the workplace, they experience job satisfaction (Bond et al. 2005). Nevertheless, contrary to this view, when employers reveal less support and concern to their subordinates' matters (Kim, Lee \& Sung 2013), workers may, in return, admire less their employers' efforts in facilitating the settlements of their staff personal work-life obligations. Eventually this shall reversely impact the workers' work behaviors at the workplace (Fransman, 2014).

Diverse research findings have displayed that improper balance between work responsibilities and life obligations shall result in severe ramifications of various trends including but not limited to stress and stress-related health problems, mismanagement of family issues and diverse, poor self-admiration, depression, lack of energy, fatigue, sleep disorders, addictions, escalated turnover rates, burnout issues, violence at the workplace, decrease in productivity levels, and reduced organizational commitment. All of this, in addition to many more consequences, shall negatively affect the overall productivity of the workplace, which will end in lower profitability in the long run (Allen et al. 2000; Anderson, Coffey \& Byerly 2002; Hämmig \& Bauer 2009; Hughes \& Bozionelos 2007; and Thomas \& Ganster, 1995).

Modern organizational structures are taking into consideration the development of work-life balance practices to assist employees in managing work-life challenges by minimizing their work-life conflicts and thus performing better at the workplace. A study on 732 manufacturing firms in Germany, France, UK, and the U.S. showed that those firms that offer better work-life balance practices experienced higher employee productivity and that adapting work-life policies shall result in higher employee levels of job satisfaction and organizational commitment.

\subsection{Work-Family Conflict}

"The topic of work-family conflict has been of particular interest because recent studies have demonstrated that $40 \%$ of employed parents experience work-family conflict for at least a period in their lives" (Allen et al., 2000). Work-family conflicts occur for many reasons, precisely this state of conflict happens when challenges at work interfere with family daily routines and sequence of family life; "pressures in the family environment might be the presence of young children, elder care responsibilities, interpersonal conflicts within the family, and the presence of unsupportive family members" (Chernyak-Hai \& Tziner, 2016; and Greenhaus, 2002). According to the Third European Working Conditions Survey (Paoli \& Merllie, 2000), which took place in 15 European countries, $10 \%$ of the surveyed workers faced the challenge of meeting their family obligations due to the long hours they spend at the workplace.

Moreover, many studies exploring the conflict resulting from the mismanagement that workers face in trying to balance their work demands and personal responsibilities highlight the negative effect of that conflict on their psychological well-being and their level of satisfaction at the workplace (Frone et al., 1992; Hughes \& Galinsky, 1994; Kossek \& Ozeki, 1998; Kinnunen \& Mauno, 1998; Cuthbertson, K., et al., 2005). 


\subsection{Work-Family Enrichment}

However, it is not always the case that work, and family are in conflict all the time, and that was the entrance for some researchers to propose the concept of work-family enrichment by Greenhaus and Powell (2006), who "defined this concept as the enhancement performance and positive affect in one role from the experiences in another role." "According to Grzywacz (2000), work-family enrichment is the positive synergy between work and family". "The work experiences might enrich the quality of family life, or family experiences might contribute to the working life quality" (Jain \& Nair, 2013; Ruikar \& Abhyankar, 2015). "Balance must be considered as a social structure, and work-family balance should be considered as an important construct when expectations of the individual and others around him/her are shared and agreed upon" (Grzywacz \& Carlson, 2007). It has been proven that work-family balance is directly linked with organizational engagement and satisfaction (Omran \& Kamel, 2016). In addition, Pattusamy and Jacob (2017). showed that "work-family balance mediates the relationship between work-family conflict and job and family satisfaction." As this concept was more and more explored by many studies, the term work-life "balance replaced work-family balance because life in this sense means everything outside work" (Carlson, Grzywacz, \& Zivnuska, 2009; and Haar, 2013). Another study done by Baral (2010) including 485 employees working in various organizations in India, revealed that "men and women in India do not experience work-family conflict whereas they feel more of family-enrichment".

\subsection{WLB Scale - Hayman (2005)}

The tool used in this research depended partially on the WLB scale developed by Hayman (2005) scale, adapted for measuring work/life balance at the companies under study. It consists of 15-item; this scale was originally adapted from an instrument developed by Fisher-McAuley et al. (2003). The scale was originally designed to capture employee perception on WLB; The original scale consists of 19 items. The scale was later simplified by constructing three dimensions. The three dimensions are: Work Interference with Personal Life (WIPL), Personal Life Interference with Work (PLIW), and Work/Personal Life Enhancement (WPLE). These three dimensions represent two theories that are usually used to explain the link between family and work; the conflict approach and the enrichment approach. These two theories are opposite to each other in terms of concept and content. The "conflict approach assumes that combining work and family roles is demanding and therefore leads to conflict" (Edwards \& Rothbard, 2000). In contrast, the "enrichment approach emphasizes that life can enrich work outcomes and vice-versa" (Greenhaus \& Powell, 2006).

\subsection{Job Satisfaction (J.S.)}

"Job satisfaction has been an area of interest for many researchers over the past several decades" (Hackman \& Oldhman, 2001).

As defined by Furnham (1997), job satisfaction is a positive feeling about the work or the work environment. Weiss, H.M. (2002) defined job satisfaction as a favorable emotional reaction and attitude that one experiences at work resulting from a "pleasurable emotional state." It was also defined as a "positive attitude" that would increase productivity (Daft \& Marcic, 2001). Others defined it as a "reflection of an employee's feelings about various aspects of work" (Stone, 2005).

Moreover, Konhauser (2005) noted that job satisfaction is positively proportionate with one's state of happiness, and that job satisfaction has also a direct link with impact employees' performance, absenteeism, effectiveness, and their decision to leave the work.

Many surveys were conducted concerning the relationship between implementing work/life balance programs and policies and job satisfaction at the workplace, and it was found that "Work-life balance is directly related to employee satisfaction" (Susi.S, 2010). As a result of these studies, it became apparent that there was a need to explore in-depth many practical terms for any organization, especially the work-family concept. As research improved in this area of study, it became highlight that Human Resource Management needs to focus more on numerous work-family friendly practices, programs, and policies, aiming to leverage job satisfaction (Kinnie et al., 2005). Robbins (2004) noticed that workers with increased job satisfaction levels experience positive behaviors towards their jobs, whereas people with decreased levels of job satisfaction have opposite behaviors at the workplace.

Eventually, many studies showed that work-life balance is positively linked to job and life satisfaction" (Haar et al., 2014)), "well-being" (Frone, 2000), "job and marital satisfaction" (Brough et al., 2014; Kossek \& Ozeki, 1998), and "negatively related to "job stress" (Behson, 2002), "anxiety and depression" (Haar et al., 2014), and "psychological strain" (Brough et al., 2014) 


\subsection{Job Satisfaction Scale - MSQ}

One of the major challenges when "measuring job satisfaction is that it is possible to be satisfied with some aspects of the job and at the same time be dissatisfied with others" (Spagnoli et al., 2012). Some of the most popular and famous tools used in measuring job satisfaction are the Minnesota Satisfaction Questionnaire (Weiss et al., 1967), the Job Descriptive Index (Smith et al., 1969), and the Job Satisfaction Survey (Spector, 1985). Whereas the second approach looks at the job satisfaction from a macro point of view and measures the employee directly by asking him/her about their overall feelings about the job, being frequently build up with only one item (Wanous et al., 1997). The Minnesota Satisfaction Questionnaire (MSQ); one of the outputs from the 'Work Adjustment Project" at the University of Minnesota and was developed by Weiss (1967) to measure job satisfaction levels. The theory underlying this work was the "assumption that work fit is dependent on the correspondence between the individual skills and the reinforcements that exist in work". The MSQ has two versions: long and short. The long version consists of 100 questions that assess 20 subscales. The subscales are: "Ability Utilization, Achievement, Activity, Advancement, Authority, Company Policies, Compensation, Co-workers, Creativity, Independence, Moral Values, Recognition, Responsibility, Security, Social Status, Social Service, Supervision--Human Relations, Supervision-Technical, Variety, Working Conditions." The MSQ short version is adapted in this study while using only 14 items of the 20 .

\subsection{Related Studies on WLB}

Over the years, many researchers conducted several studies on the relationship between WLB and job satisfaction. "Nadeem \& Abbas (2009) conducted a study in Pakistan to analyze the relationship between WLB and job satisfaction". The research was based on data collected from 157 employees working in the public and private sectors. The results of their study showed that work overload does not influence job satisfaction.

Another study conducted by Mcnall et al. (2009) analyzed the "relationship between flexible work arrangements and job satisfaction." The research was based on data collected from 220 employees. This study indicates that employees obtaining greater flexibility in companies' work arrangements, they experience higher satisfaction levels.

Later (Varatharaj et al., 2012) conducted another study in Chennai city to examine the relationship between job satisfaction and WLB. The research was based on data collected from 250 employees from different service sectors. The results of this study showed that WLB and job satisfaction share a positive relationship.

Moreover, research to analyze the relationship between work-life balance and job satisfaction of the working women was conducted by Yadav \& Dabhade (2014). The research collected data from 150 women, half from the banking sector and a half from the education sector. The study results revealed the extent of the employees' commitment to their jobs that they do not put behind them if they face urgent living conditions.

Here, it is necessary to point out the need for the company's management to pay attention to these matters to ensure the best productivity by relying on creating a better state of purity in the relationship between life and work matters by providing support to them in how to control their life responsibilities and balance them with work responsibilities.

\section{Methodology}

In this study, Hayman (2005) simplified Work-Life Balance Scale, and the Minnesota Satisfaction Questionnaire (MSQ) (Weiss et al., 1967) are used to achieve an answer to the research questions and to conduct the research findings.

\subsection{Methods of Data Analysis and Interpretation}

The data was captured into an access database where consistency checks were enforced. After completion of data entry, data were exported into SPSS for statistical analysis.

Simple statistical tools such as mean, range, and percentage have been used to analyze quantitative data. Other techniques were applied to check multi-collinearity and the correlations between the targeted questions as groups or as individual ones and the homoscedasticity, including Pearson's correlation coefficient test and multi-regression. For general characteristics of the sample, frequencies and cross-tabulation techniques were also applied. To reflect the changes applied to the negatively stated questions, the values of the five-category scale for the corresponding questions were also reversed as follows: 
Table 1. Vales of Corresponding Questions

\begin{tabular}{ll}
\hline Value & Score \\
\hline Strongly Disagree & Strongly Agree \\
Disagree & Agree \\
Hesitated/Not Sure & Hesitated/Not Sure \\
Agree & Disagree \\
Strongly Agree & Strongly Disagree \\
\hline
\end{tabular}

Before data analysis, the values of the five-category scale of the instrument were weighted from zero to five according to the following scoring table:

Table 2. Scoring Table

\begin{tabular}{ll}
\hline Value & Score \\
\hline Strongly Disagree & 0 \\
Disagree & 25 \\
Hesitated/Not Sure & 50 \\
Agree & 75 \\
Strongly Agree & 100 \\
\hline
\end{tabular}

\subsection{The Questionnaire}

Some of the items in the instrument were negatively phrased. Before data analysis, these items were subjected to value conversion from negative to positive phrasing.

\subsection{Data Collection and Sampling}

The research population which according to (Sekaran, 2005) refers to the entire group of people, events, or things of interest that the researcher wishes to investigate; This study targeted a random sample of 932 employees on top of their positions at 7 different companies at the private sector in Palestine. The respondents were asked to fill an online self-reported questionnaire. The questionnaire was administered on the online platform 'SurveyMonkey' and an online link was distributed to all HR departments in the 7 companies under study. The HR managers took the responsibility to distribute the link among their employees with consideration to hand out a total of 173 questionnaire to workers that do not have access to online resources. Of the 932 employees, 502 employees submitted back the questionnaire; where 2 questionnaires of the total number received back were considered incomplete responses and thus were excluded from the analysis phase. According to Mugenda and Mugenda (1999), a response rate of 50\% is adequate for the analysis and reporting; a rate of $60 \%$ is reasonable, and a response rate of $70 \%$ and over is excellent. The current study's response rate was 54\%, which is satisfactory and adequate to make conclusions of the study as it acted as a representative. Therefore, 500 responses were administered for analysis, making a response rate of $54 \%$. The questionnaire was administered in Arabic as many employees might face difficulty filling a questionnaire in English, which could affect the quality of their responses.

\subsection{Research Design}

The questionnaire is the research instrument used in this study, and it is partially adopted from both the Hayman (2005) scale and the short version of the MSQ. The first section looks for demographic data that is crucial for the study and consists of 12 items: Gender, age, education, marital status, residents under one roof, number of years working with current employer, rank at current job, employment status, monthly income.

The second section assesses the WLB of the employees, which was based on the three constructs of Hayman (2005). This scale was originally adapted from an instrument developed by Fisher-McAuley et al., (2003). This scale was originally designed to capture employee perception on WLB; The original scale consists of 19 items and three dimensions of work-life balance. They simplified the WLB concept by placing three dimensions. The three dimensions are: Work Interference with Personal Life (WIPL), Personal Life Interference with Work (PLIW), and Work/Personal Life Enhancement (WPLE). These three dimensions represent two theories that are usually used to explain the link between family and work. The first approach is the conflict approach and the second is the enrichment approach. These two theories are opposite to each other in terms of concept and content. The conflict approach assumes that combining work and family roles is demanding and therefore leads to conflict (Edwards \& Rothbard, 2000). Whereas the enrichment approach emphasizes that life can enrich work outcomes and vise-versa (Greenhaus \& Powell, 2006). This scale has been used by other researchers (e,g. 
Hayman, 2005). A short description of the three constructs of WLB as presented by Hayman (2005) is exhibited below:

\section{Work Interference with Personal Life (WIPL)}

This construct includes work related factors that impact an individual's personal life. It measures the impact of work on personal life. This construct measures 7 items which are:

1- My personal life suffers because of work

2- My job makes my personal life difficult

3- I neglect personal needs because of work

4- I put personal life on hold for work

5- I miss personal activities because of work

6- I struggle to juggle work and non-work

7- I am unhappy with the amount of time for non-work activities

Personal Life with Work Interference (PLIW)

This construct has been explained as the impact of personal life on work. It measures the impact of personal life on one's work. This construct measures 4 items which are:

1- My personal life drains me of energy for work

2- I am too tired to be effective at work

3- My work suffers because of my personal life

4- It is hard to work because of personal matters

\section{Work Personal Life Enhancement (WPLE)}

This construct explains how work and personal life enhance each other, it helps to understand how work supports and enhances personal life and jhow personal life supports and enhances work. This construct consists of 4 items, which are:

1- My personal life gives me energy for my job

2- My job gives me energy to pursue personal activities

3- I have a better mood at work because of personal life

4- I have a better mood because of my job

The third section in the questionnaire measures the employee job satisfaction. Some of the most popular measures in the field that adopted this perspective was the Minnesota Satisfaction Questionnaire (Weiss et al., 1967). The MSQ have two versions: long and short. The long version consists of 100 questions that assess 20 subscales. The subscales are: Ability Utilization, Achievement, Activity, Advancement, Authority, Company Policies, Compensation, Co-workers, Creativity, Independence, Moral Values, Recognition, Responsibility, Security, Social Status, Social Service, Supervision--Human Relations, Supervision-Technical, Variety, Working Conditions.

The long version was then modified to a shorter version of the MSQ that consists of 20 items only. However, this paper adapted only 14 items of MSQ as the Palestinian context matches most of the 14 items selected.

The fourth section consisted of 8 items and was developed by the researcher. This section answers the fourth research question, which is to measure the relationship between WLB and J.S.

The fifth section and consists of 14 items, and looks for other data needed, concerning the WLB programs that employees are willing to have. This was necessary to provide the human resource departments of the companies under study with data needed to improve their strategic planning concerning the WLB and job satisfaction of their employees. Responses are made on a 5-point Likert scale, and the response categories are assigned weights from 1 to 5 .

\section{Research Findings and Discussion}

Data analysis involves several closely related operations that are performed to summarize the collected data and organize them in such a manner that they answer the research questions (Sekaran, 2005). 


\subsection{Validity and Reliability Analysis}

Content validity was measured based on reviewing and approving of the questionnaire content by three experts in the field of HRM; working as researchers and educators at Birzeit University in Palestine.

Cronbach's alpha was used as a measure of scale reliability, in other words, to measure internal consistency between each related set of items. Its values for all sections of the questionnaire are ranged between 0.77 and 0.90 per section, which are suitable for excellent reliability values. The main two sets of items (WLB \& JS) covered by the analysis are consistent with it and stand within the same range, as shown in table 1: 0.77, 0.78, 0.81 , and 0.90 . Moreover, the overall value of this factor (the instrument as a whole) was 0.87 , indicating a high degree of stability for the instrument used in this research.

The correlation for all items of the questionnaire is strong enough and significant with the tool. The only exception is for the $6^{\text {th }}$ statement in the WLB part in the instrument, which is "I struggle to juggle work and non-work" this indicates the strength of the internal consistency between the parts of the tool (the questionnaire) in measuring the balance between work and life responsibilities with job satisfaction.

Table 3. Validity and reliability analysis

\begin{tabular}{ll}
\hline Variable & Cronbach alpha \\
\hline Work-Life Balance (WLB) & 0.81 \\
Work interference with personal life (WIPL) & 0.78 \\
Personal Life interference with (PLIW) & 0.77 \\
Work Personal Life Enrichment & 0.81 \\
Job Satisfaction (J.S.) & 0.90 \\
\hline
\end{tabular}

\subsection{Descriptive Statistics: Demographic data}

The total number of the participants was 502 , of which about $81 \%$ were males, and $19 \%$ were females. $25 \%$ of the participants are age between 18-24 years, 51\% age between $25-34$ years, while $17 \%$ age between $35-44$ years. The age group between $45-54$ years old composed 6\%, whereas a marginal percentage (less than 1\%) was 55 years and above.

In terms of the educational level, $72 \%$ of the total number of participants carry undergraduate certificates, $7 \%$ hold a master's degree, while $21 \%$ hold a secondary school certificate.

About work experience, a third of the participants (32\%) are well experienced with eight years and more, while those who have less than two years of work experience compose $47 \%$ and $21 \%$ with 3-7 years. Further, $28 \%$ of participants work in supervisory positions, $62 \%$ as professional jobholders, and $10 \%$ work in support services positions. Moreover, $47 \%$ of the surveyed persons are married, $52 \%$ are single, while $1 \%$ in other marital status positions. In terms of their employment type, $94 \%$ of them have full-time job contracts while the rest are part-time employees.

Concerning the salary range, almost half of the participants (47\%) earn 3,000ILS (about 850US\$), 36\% earn between 3001-6000ILS (851-1700US\$), 10\% earn 6001-9000ILS (1701-2250 US\$), and the remaining earn more than 9000ILS (2250 US\$).

The family structure for the sampled employees ranged between 2-7 persons per family; almost half of the participants family structure (47\%) range between 2-4 persons and 44\% range between 5-7 persons, while 5\% of the families are with eight persons and more and only $3 \%$ are single-person families. 
Table 4. Demographic Data: Participant's Profile

\begin{tabular}{|c|c|c|c|}
\hline Demographic Variable & Categories & Frequencies & Percentage \\
\hline \multirow[t]{2}{*}{ Gender } & Males & 408 & $81.3 \%$ \\
\hline & Females & 94 & $18.7 \%$ \\
\hline \multirow[t]{5}{*}{ Age } & 18-24 years & 126 & $25.1 \%$ \\
\hline & $25-34$ years & 258 & $51.4 \%$ \\
\hline & $35-44$ years & 86 & $17.1 \%$ \\
\hline & $45-55$ years & 28 & $5.6 \%$ \\
\hline & 55 years and & 4 & $0.8 \%$ \\
\hline \multirow[t]{4}{*}{ Education } & High School Diploma & 104 & $20.9 \%$ \\
\hline & Diploma & 43 & $8.6 \%$ \\
\hline & Bachelor & 314 & $63.1 \%$ \\
\hline & Master and above & 37 & $7.4 \%$ \\
\hline \multirow[t]{5}{*}{ Experience } & Less than one year & 92 & $18.3 \%$ \\
\hline & 1-2 years & 145 & $28.9 \%$ \\
\hline & 3-7 years & 103 & $20.5 \%$ \\
\hline & $8-10$ & 78 & $15.5 \%$ \\
\hline & 11 years and above & 84 & $16.7 \%$ \\
\hline \multirow[t]{4}{*}{ Job Title } & Manager & 50 & $10.0 \%$ \\
\hline & Supervisor & 89 & $17.8 \%$ \\
\hline & Officer & 309 & $61.7 \%$ \\
\hline & Worker & 53 & $10.6 \%$ \\
\hline \multirow[t]{3}{*}{ Marital status } & Not married & 234 & $46.9 \%$ \\
\hline & Married & 259 & $51.9 \%$ \\
\hline & Other & 6 & $1.2 \%$ \\
\hline \multirow[t]{3}{*}{ Current position } & Full job & 469 & $94.2 \%$ \\
\hline & Part-time job & 26 & $5.2 \%$ \\
\hline & Other & 3 & $0.6 \%$ \\
\hline \multirow{4}{*}{$\begin{array}{l}\text { Number of persons per } \\
\text { family }\end{array}$} & One person & 15 & $3.0 \%$ \\
\hline & 2-4 persons & 237 & $47.4 \%$ \\
\hline & 5-7 persons & 222 & $44.4 \%$ \\
\hline & Eight persons and above & 26 & $5.2 \%$ \\
\hline \multirow[t]{6}{*}{ Monthly income } & Less than 3000 NIS & 236 & $47.2 \%$ \\
\hline & 3001-6000 NIS & 178 & $35.6 \%$ \\
\hline & 6001-9000 NIS & 48 & $9.6 \%$ \\
\hline & 9001-12000 NIS & 18 & $3.6 \%$ \\
\hline & 12001-20000 NIS & 15 & $3.0 \%$ \\
\hline & 20001 and more & 1 & $1.0 \%$ \\
\hline
\end{tabular}

\subsection{Main Results}

The means of the items that compose the work-life balance scored differ from the values that reflect differences in its contribution to have the balance of the work-life; the highest mean was about 80 for two items ("My work suffers because of personal matters" and "It is hard to work because of personal matters") with a relative standard deviation of 19-20. On the other hand, the lowest was represented in three statements ("I put personal life on hold for work" and "I miss personal activities because of work" and "My job gives me the energy to pursue personal activities") which scored 48 with a higher standard deviation of about 29-30 for each of the three items. Whereas concerning the Job Satisfaction, the highest score of the item means was almost 79 , followed by 72 ("Being able to do things that do not go against my conscience" and "The chance to be "somebody" in the community") at a standard deviation of about 26.5 each. On the lowest score, it was 42 and 40 accordingly ("The chances for advancement on this job" and "My pay and the amount of work I do") with a standard deviation of about 31. This gives a clear idea of how these items contributed to achieving job satisfaction. Table 4 goes about here. 
Table 5. Descriptive statistics

\begin{tabular}{|c|c|c|c|c|c|}
\hline Variable & $N$ & Minimum & Maximum & Mean & $\begin{array}{l}\text { Std. } \\
\text { Deviation }\end{array}$ \\
\hline QII_1 & 498 & 0 & 100 & 55.07 & 31.209 \\
\hline QII_2 & 499 & 0 & 100 & 55.26 & 30.493 \\
\hline QII_3 & 502 & 0 & 100 & 49.80 & 30.628 \\
\hline QII_4 & 502 & 0 & 100 & 48.11 & 29.827 \\
\hline QII_5 & 495 & 0 & 100 & 47.53 & 29.932 \\
\hline QII_6 & 495 & 0 & 100 & 67.37 & 29.609 \\
\hline QII_7 & 497 & 0 & 100 & 50.65 & 29.286 \\
\hline QII_8 & 497 & 0 & 100 & 70.12 & 26.989 \\
\hline QII_9 & 498 & 0 & 100 & 72.34 & 25.309 \\
\hline QII_10 & 499 & 0 & 100 & 80.26 & 19.498 \\
\hline QII_11 & 499 & 0 & 100 & 79.86 & 20.661 \\
\hline QII_12 & 497 & 0 & 100 & 62.83 & 27.270 \\
\hline QII_13 & 496 & 0 & 100 & 48.64 & 29.292 \\
\hline QII_14 & 499 & 0 & 100 & 58.57 & 27.404 \\
\hline QII_15 & 497 & 0 & 100 & 54.98 & 29.386 \\
\hline QIII_I & 499 & 0 & 100 & 64.13 & 26.240 \\
\hline QIII_2 & 499 & 0 & 100 & 71.84 & 26.488 \\
\hline QIII_3 & 494 & 0 & 100 & 70.24 & 27.902 \\
\hline QIII_4 & 496 & 0 & 100 & 78.83 & 26.552 \\
\hline QIII_5 & 493 & 0 & 100 & 67.55 & 25.780 \\
\hline QIII_6 & 492 & 0 & 100 & 63.31 & 29.517 \\
\hline QIII_7 & 497 & 0 & 100 & 40.14 & 31.244 \\
\hline QIII_8 & 497 & 0 & 100 & 42.20 & 31.444 \\
\hline QIII_9 & 496 & 0 & 100 & 58.67 & 28.390 \\
\hline QIII_10 & 496 & 0 & 100 & 63.71 & 27.174 \\
\hline QIII_11 & 498 & 0 & 100 & 61.35 & 29.144 \\
\hline QIII_12 & 500 & 0 & 100 & 67.90 & 27.994 \\
\hline QIII_13 & 500 & 0 & 100 & 57.85 & 30.273 \\
\hline QIII_14 & 499 & 0 & 100 & 62.93 & 28.794 \\
\hline
\end{tabular}

\subsection{The Impact of Work Life Balance on Job Satisfaction}

Multiple regression model was applied to find out the association between the three components of work-life balance (as independent variables); which are work interference with personal life (WIPL), personal life interference with work (PLIW), and work personal life enrichment (WPLE) with job satisfaction (as dependent variable).

The results of the standard multiple regression indicated that the overall model was a statistically significant predictor of Job satisfaction, $F(3,496)=66.158, \mathrm{p}=.000$.

Around $31 \%$ of the variances in the data (Job satisfaction) can be explained by the three predictor variables of work-life balance (WLB); which are work interference with personal life (WIPL), personal life interference with (PLIW), and work personal life enrichment (WPLE).

The three predictor variables of work-life balance (WLB), work interference with personal life (WIPL), personal life interference with work (PLIW), and work personal life enrichment (WPLE) significantly contributed to the model (P-value $=.000, .033, .000$ respectively).

Personal life interference with work (PLIW) $(B 1=0.371)$ : as employees' attitude towards work interference with personal life gets more positive (less interference), their attitude towards Job satisfaction increases by 0.371 units.

Work interference with personal life (WIPL) $(\mathrm{B} 2=0.099)$ : as employees' attitude towards personal life interference with work gets more positive (less interference), their attitude towards Job satisfaction increases by 0.099 units.

Work personal life enrichment $(\mathrm{B} 3=0.193)$ : as employees' attitudes towards work personal life enrichment get more positive, their attitude towards Job satisfaction increases by 0.193 units.

Based on these results, it is significant that both main variables strongly correlated as it is 0.0 at level $(\mathbf{( 0 . 0 5} \leq \boldsymbol{\alpha}$, which means less than 0.5 , so the hypothesis rejected (main research questions). 
Table 6. Multiple regression model (Dependent: Job Satisfaction)

\begin{tabular}{llllll}
\hline & \multicolumn{2}{l}{$\begin{array}{l}\text { Unstandardized } \\
\text { Coefficients }\end{array}$} & & & \\
\cline { 1 - 4 } Model I & $\boldsymbol{\beta}$ & St. Error & T-statistics & P-value & Null Hypothesis \\
\hline Constant & 24.680 & 3.626 & 6.806 & 0.000 & Reject \\
Group_QIIA & 0.371 & 0.041 & 9.029 & 0.000 & Reject \\
Group_QIIB & 0.099 & 0.046 & 2.144 & 0.033 & Reject \\
Group_QIIC & 0.193 & 0.035 & 5.530 & 0.000 & Reject \\
R Square & 0.307 & $\boldsymbol{F}$-Statistic & 66.158 & Sig & $.000^{b}$ \\
\hline
\end{tabular}

\subsection{Struggling in Reconciling Work with Life Commitments}

Wilcoxon signed ranks test had been done to check whether the employees are struggling to juggle work and other life responsibilities and commitments, which indicated that their attitudes were significantly toward approving and strongly approving this struggle (the median $>50), \mathrm{z}=78,858.5, \mathrm{P}_{-}$value $=.000$. Thus, it can be concluded that the employees are struggling with reconciling work and life commitments.

Table 7. Wilcoxon Test

\begin{tabular}{|c|c|c|c|c|}
\hline & \multirow[t]{2}{*}{ Median } & \multirow{2}{*}{$\begin{array}{l}\mathrm{N}(\%) \\
\text { (agree \& strongly } \\
\text { agree) }\end{array}$} & \multicolumn{2}{|c|}{$\begin{array}{l}\text { A one-sample Wilcoxon signed ranks } \\
\text { test. }\end{array}$} \\
\hline & & & z statistic & $P_{\text {_value }}$ \\
\hline $\begin{array}{l}\text { Struggling in reconciling work and life } \\
\text { commitments }\end{array}$ & 75 & 339 (67.4) & $78,858.5$ & .000 \\
\hline
\end{tabular}

\subsection{WLB Programs that could Improve Status of Work-Life Balance}

As one of the research's objectives is to develop some recommendations in terms of the most desirable work-life balance programs by the selected sample at the companies under study, further data was analyzed, and it revealed four main types of programs as indicated by the employees from their point of view. The first one is related to health insurance and complementary health program, including fitness and health guidance and entertainment that aims to reduce the workload; this cluster scored about $91 \%$. The second important program is related to children's care, such as medical care programs, and this cluster scored about $80 \%$. The third one is the flexibility in working hours with a score of about $75 \%$. In comparison, the fourth level refers to providing affordable meals for the employees, reflected by $75 \%$ of the employees. Table 7 exhibits all proposed work-life balance programs with related percentages ranked from most to least important as been filled by the sample under study.

Table 8. WLB Programs that could improve status of work-life balance

\begin{tabular}{ll}
\hline Work-Life Balance Programs Importance to Sampled Employees & $\%$ \\
\hline Health insurance for dependent parents & $90.7 \%$ \\
Comprehensive wellness programs (gym membership, nutrition seminars, recreational trips to relieve work & $90.9 \%$ \\
stress, Etc.) & $80.3 \%$ \\
Sick childcare program (counting absence from work for sick childcare as part of the employee's sick leave) & $75.5 \%$ \\
Variable starting/ending hours & $75.0 \%$ \\
Paternity leave (no less that one week) & $74.6 \%$ \\
Providing take away healthy meals at affordable prices & $67.6 \%$ \\
Reduced workweek schedule & $57.9 \%$ \\
Compressed work schedule & $56.9 \%$ \\
Extended maternity leave (with position guarantee) & $50.5 \%$ \\
Home/mobile Working & $45.1 \%$ \\
Support for Family Counseling services & $40.8 \%$ \\
Job Sharing & $38.0 \%$ \\
Onsite childcare center & \\
\hline
\end{tabular}

\section{Study Limitations}

One major limitation was that some of the respondents did not have access to emails. Those respondents were mostly from the worker's level, thus were given hard copies to fill. Another limitation was the language as the 
questionnaire was translated from English into Arabic as most respondents feel more at ease when reading Arabic.

\section{Conclusion}

It is evident from the study results that the average effect of work matters on personal life and the effect of life on work matters is strongly confirmed, which indicates clarity on the impact of work matters during the course of life. Moreover, there is a clear view on the impact of employee life matters on their jobs, which confirms the fact that the employees cannot completely separate work from their personal life, and that both personal matters and work are normally overlapped. The revealed relationship between work-life balance and job satisfaction indicates the research's consistency that was designed based on previous experiences, as indicated in the literature review.

Lastly and after an intensive literature review concerning the many definitions of the term work-life balance across the last 30 years, the researcher would come up with own contribution to the term WLB, and state it as 'reaching a state of equilibrium where each worker personally decides on the extended boundaries of interference crossing between life demands and work responsibilities.

\section{Recommendations}

This study shall aid the companies involved with managerial tools that would assist their Human Resource Departments (HRD) to enhance its employees' mental life and working conditions in order achieve higher employees' performance levels. Referring to the research findings, the following recommendations made by the research writer:

- It takes in different adaptations by organizations to assist employees to have better life conditions and thus become more productive at the workplace; with matching and appropriate WLB policies and programs in place, the companies under study shall expect higher employee satisfaction.

- Management's support at the different companies to the concept of WLB is crucial to achieve higher level of JS. It is even more apparent for top managements and precisely executive people and leaders to set the standards for WLB practices and apply them across the different managerial levels at their companies.

- Considering a breakdown of the overall JS results across the different 7 companies under study shall give each and every company the chance to dig deeper into the results and focus on designing matching WLB practices that would enhance the quality of their lives and the time split between work and family commitments, thus ending into satisfying their needs and achieving higher JS rates.

- Sponsoring health insurance programs for dependent parents along with offering wellness programs are obvious good opportunities to help employees strike a new standard in balancing work and life matters.

- Companies' managements need to commit to the concept of WLB and start adapting its most common practices by having them announced in their HR handbooks and implementing these practices among their employees.

- Train the HR departments on the different newly adapted WLB applications and practices. In addition, setting up coaching sessions shall assist and support better communications and understanding of their employees needs and challenges.

\section{Future Research}

Further work is recommended to extend this research by doing additional in-depth analysis to uncover more details of these interrelationships up to the formulation of a unique model that leads to creating a state of job satisfaction based on the balance between personal life and work responsibilities, as well the possibility of adapting it in different circles in the field of business, especially on other important Palestinian sectors like the public sector. Moreover, another research might be interesting is to study the current research aspects from a deeper gender perspective.

\section{References}

Allen, T. D., Herst, D. E., Bruck, C. S., \& Sutton, M. (2000). Consequences associated with work-to-family conflict: a review and agenda for future research. Journal of occupational health psychology, 5(2), 278. https://doi.org/10.1037/1076- 8998.5.2.278

Anderson, S. E., Coffey, B. S., \& Byerly, R. T. (2002). Formal organizational initiatives and informal workplace practices: Links to work-family conflict and job-related outcomes. Journal of management, 28(6), 787-810.

Baral, R. (2010). Work-family enrichment: Benefits of combining work and family. 
Beauregard, T. A., \& Henry, L. C. (2009). Making the link between work-life balance practices and organizational performance. Human resource management review, 19(1), 9-22. https://doi.org/10.1016/j.hrmr.2008.09.001

Behson, S. J. (2002). Coping with family-to-work conflict: The role of informal work accommodations to family. Journal of occupational health psychology, 7(4), 324. https://doi.org/10.1037/1076-8998.7.4.324

Berg, P., Kalleberg, A. L., \& Appelbaum, E. (2003). Balancing work and family: The role of high-commitment environments. Industrial Relations: A Journal of Economy and Society,42(2), 168-188. https://doi.org/10.1111/1468-232X.00286

Berry, E. (2010). Achieving work-life balance: More than just a juggling act. American Medical News.

Bond, J. T., Galinsky, E., Kim, S. S., \& Brownfield, E. (2005). National study of employers. New York: Families and Work Institute, 6 .

Bosworth, D., \& Hogarth, T. (2009). Future horizons for work-life balance. Institute for Employment Research, University of Warwick.

Brough, P., Timms, C., O'Driscoll, M. P., Kalliath, T., Siu, O. L., Sit, C., \& Lo, D. (2014). Work-life balance: A longitudinal evaluation of a new measure across Australia and New Zealand workers. The International Journal of Human Resource Management, 25(19), 2724-2744. https://doi.org/10.1080/09585192.2014.899262

Carlson, D. S., Grzywacz, J. G., \& Zivnuska, S. (2009). Is work-family balance more than conflict and enrichment? Human relations, 62(10), 1459-1486. https://doi.org/10.1177/0018726709336500

Chandra, V. (2012). Work-life balance: eastern and western perspectives. The International Journal of Human Resource Management, 23(5), 1040-1056. https://doi.org/10.1080/09585192.2012.651339

Chernyak-Hai, L., \& Tziner, A. (2016). The "I believe" and the "I invest" of Work-Family Balance: The indirect influences of personal values and work engagement via perceived organizational climate and workplace burnout. Revista de Psicología del Trabajo y de las Organizaciones, 32(1), 1-10. https://doi.org/10.1016/j.rpto.2015.11.004

Cuthbertson, K., \& Nitzsche, D. (2005). Quantitative financial economics: stocks, bonds and foreign exchange. John Wiley \& Sons.

Daft, T. S., \& Marcic, D. W. (2001). Job satisfaction and the good soldier: The relationship between affect and employee "citizenship". Academy of management Journal, 26(4), 587-595. https://doi.org/10.2307/255908

Darcy, C., McCarthy, A., Hill, J., \& Grady, G. (2012). Work-life balance: One size fits all? An exploratory analysis of the differential effects of career stage. European Management Journal,30(2), 111-120. https://doi.org/10.1016/j.emj.2011.11.001

Dockel, A. 2003. The Effect of Retention Factors on Organizational Commitment: An Investigation of High Technology Employees. Master of Human Resource Thesis. University of Pretoria.

Edwards, J. R., \& Rothbard, N. P. (2000). Mechanisms linking work and family: Clarifying the relationship between work and family constructs. Academy of management review, 25(1), 178-199. https://doi.org/10.5465/amr.2000.2791609

Eisenberger, R., Huntington, R., Hutchison, S., \& Sowa, D. (1986). Perceived organizational support. Journal of Applied psychology, 71(3), 500-507. https://doi.org/10.1037/0021-9010.71.3.500

Estes, S. B., \& Michael, J. (2005). Work-family policies and gender inequality at work: A Sloan Work and Family Encyclopedia entry.

Families, W. (2009). New ways to work and the Working Mother's association in the United Kingdom.

Felstead, A., Jewson, N., Phizacklea, A., \& Walters, S. (2002). Opportunities to work at home in the context of work-life balance. Human resource management journal, 12(1), 54-76. https://doi.org/10.1111/j.1748-8583.2002.tb00057.x

Fisher-McAuley, G., Stanton, J., Jolton, J., \& Gavin, J. (2003, April). Modelling the relationship between work life balance and organisational outcomes. In Annual Conference of the Society for Industrial-Organisational Psychology. Orlando (pp. 1-26). https://doi.org/10.1037/e518712013-236

Fransman, E. I. (2014). Determining the impact of flexible work hours on women employed in a higher education institution (Doctoral dissertation). 
Frone, M. R. (2000). Work-family conflict and employee psychiatric disorders: The national comorbidity survey. Journal of Applied psychology, 85(6), 888. https://doi.org/10.1037/0021-9010.85.6.888

Frone, M. R., Russell, M., \& Cooper, M. L. (1992). Antecedents and outcomes of work-family conflict: testing a model of the work-family interface. Journal of applied psychology, 77(1), 65. https://doi.org/10.1037/0021-9010.77.1.65

Furnham, A. (1997). The Psychology of Behavior at Work. Hove: Psychology Press.

Glynn, C., Steinberg, I., \& McCartney, C. (2002). Work-life balance: The role of the manager (pp. 1-96). Horsham: Roffey Park Institute.

Greenhaus, J. H. (2002). Work-family conflict. Journal of The Academy of Management Review, 45, 1-9.

Greenhaus, J. H., \& Powell, G. N. (2006). When work and family are allies: A theory of work-family enrichment. Academy of management review, 31(1), 72-92. https://doi.org/10.5465/amr.2006.19379625

Grover, S. L., \& Crooker, K. J. (1995). Who appreciates family-responsive human resource policies: The impact of family-friendly policies on the organizational attachment of parents and non-parents. Personnel psychology, 48(2), 271-288. https://doi.org/10.1111/j.1744-6570.1995.tb01757.x

Grzywacz, J. G. (2000). Work-family spillover and health during midlife: is managing conflict everything? American Journal of Health Promotion, 14(4), 236-243. https://doi.org/10.4278/0890-1171-14.4.236

Grzywacz, J. G., \& Carlson, D. S. (2007). Conceptualizing work-family balance: Implications for practice and research. Advances in developing human resources, 9(4), 455-471. https://doi.org/10.1177/1523422307305487

Haar, J. M. (2013). Testing a new measure of work-life balance: A study of parent and non-parent employees from New Zealand. The International Journal of Human Resource Management, 24(17), 3305-3324. https://doi.org/10.1080/09585192.2013.775175

Haar, J. M., Russo, M., Suñe, A., \& Ollier-Malaterre, A. (2014). Outcomes of work-life balance on job satisfaction, life satisfaction and mental health: A study across seven cultures. Journal of Vocational Behavior, 85(3), 361-373. https://doi.org/10.1016/j.jvb.2014.08.010

Hackman, L. W., \& Oldhman, P. V. 2001. Organizational commitment, job satisfaction, and turnover among psychiatric technicians, Journal of applied psychology, 59(5), 603. https://doi.org/10.1037/h0037335

Hämmig, O., \& Bauer, G. (2009). Work-life imbalance and mental health among male and female employees in Switzerland. International journal of public health, 54(2), 88-95. https://doi.org/10.1007/s00038-009-8031-7

Hayman, J. (2005). Psychometric assessment of an instrument designed to measure work life balance. Research and practice in human resource management, 13(1), 85-91.

Hill, E. J., Hawkins, A. J., Ferris, M., \& Weitzman, M. (2001). Finding an extra day, a week: The positive influence of perceived job flexibility on work and family life balance. Family Relations, 50(1), 49-65. https://doi.org/10.1111/j.1741-3729.2001.00049.x

Holliday, M., \& Manfredi, S. (2004). Work-life balance: an audit of staff experience at Oxford Brookes University. The centre of diversity policy research: Oxford Brookes University.

Hughes, D. L., \& Galinsky, E. (1994). Gender, job and family conditions, and psychological symptoms. Psychology of Women Quarterly, 18(2), 251-270. https://doi.org/10.1111/j.14716402.1994.tb00454.x

Hughes, J., \& Bozionelos, N. (2007). Work-life balance as source of job dissatisfaction and withdrawal attitudes. Personnel Review, 36(1), 145-154. https://doi.org/10.1108/00483480710716768

Jain, S., \& K. Nair, S. (2013). Research on work-family balance: A review. Business Perspectives and Research, 2(1), 43-58. https://doi.org/10.1177/2278533720130104

Kim, H., Lee, J. K., \& Sung, S. (2013). The effects of family-friendly practices and gender discrimination on job attitudes: The moderating role of supervisor support. The International Journal of Human Resource Management, 24(20), 3921-3938. https://doi.org/10.1080/09585192.2013.789442

Kinnie, N., Hutchinson, S., Purcell, J., Rayton, B., \& Swart, J. (2005). Satisfaction with HR practices and commitment to the organisation: why one size does not fit all. Human Resource Management Journal, 15(4), 9-29. https://doi.org/10.1111/j.1748-8583.2005.tb00293.x 
Kinnunen, U., \& Mauno, S. (1998). Antecedents and outcomes of work-family conflict among employed women and men in Finland. Human Relations, 51(2), 157-177. https://doi.org/10.1023/A:1016962202639

Kornhauser, S. E. (2005). Job satisfaction and organizational commitment as predictors of organizational citizenship and in-role behaviors, Journal of management, 17(3), 601-617. https://doi.org/10.1177/014920639101700305

Kossek, E. E., \& Lobel, A. (1996). Managing diversity. Blackwell Publishers

Kossek, E. E., \& Ozeki, C. (1998). Work-family conflict, policies, and the job-life satisfaction relationship: A review and directions for organizational behavior-human resources research. Journal of Applied Psychology, 83(2), 139-149. https://doi.org/10.1037/0021-9010.83.2.139

Kuzulu, E., Kurtuldu, S., \& Özzkan, G. V. (2013). Is s Yas am Dengesi ile Yas sam Doyumu _ Ilis sisi U” zerine Bir Aras,tirma. [A research on the relationship between work-life balance and life satisfaction]. The Sakarya Journal of Economics, 2(1), 88-127.

Lewis, S. (2000). Restructuring workplace cultures: the ultimate work-family challenge? Women in Management Review, 16(1), 21-29. https://doi.org/10.1108/09649420110380256

Lockwood, N. R. (2003). Work/Life Balance: Challenges and Solutions, Society for Human Resource Management. Research Quarterly, 2, 1-10.

Maxwell, G. A., \& McDougall, M. (2004). Work-life balance: Exploring the connections between levels of influence in the UK public sector. Public Management Review, 6(3), 377-393. https://doi.org/10.1080/1471903042000256547

McNall, L. A., Masuda, A. D., \& Nicklin, J. M. (2009). Flexible work arrangements, job satisfaction, and turnover intentions: The mediating role of work-to-family enrichment. The Journal of psychology, 144(1), 61-81. https://doi.org/10.1080/00223980903356073

Mugenda, O. M., \& Mugenda, A. G. (1999). Research Methods: Quantitative and Qualitative Approaches. Acts Press.

Munn, S. L. (2013). Unveiling the work-life system: the influence of work-life balance on meaningful work. Advances in Developing Human Resources, 15(4), 401-417. https://doi.org/10.1177/1523422313498567

Myers, C. S. (1924). Industrial Psychology in Great Britain. London: Cape. [AQ10.28] New Consultant Headquarters 2011. 7 tips to create work-life balance when you work from home.

Nadeem, M. S., \& Abbas, Q. (2009). The impact of work life conflict on job satisfactions of employees in Pakistan. International Journal of Business and Management, 4(5), 63-83. https://doi.org/10.5539/ijbm.v4n5p63

Omran, S., \& Kamel. A. (2016). Work-family balance dilemma among employed parents (An empirical study). International Journal of Business and Economic Development (IJBED), 4(1), 31-46.

Paoli, P., \& Merllié, D. (2000). European Foundation for the Improvement of Living and Working Conditions-Third European survey on working conditions.

Parakati, V. (2010). The history of work-life balance: it's not as new as you might think. Examiner. com.

Pattusamy, M., \& Jacob, J. (2016). Testing the mediation of work-family balance in the relationship between work-family conflict and job and family satisfaction. South African Journal of Psychology, 46(2), 218-231. https://doi.org/10.1177/0081246315608527

Pattusamy, M., \& Jacob, J. (2017). A test of Greenhaus and Allen (2011) model on work-family balance. Current Psychology, 36(2), 193-202. https://doi.org/10.1007/s12144-015-9400-4

Peeters, M. C., Montgomery, A. J., Bakker, A. B., \& Schaufeli, W. B. (2005). Balancing work and home: How job and home demands are related to burnout. International Journal of Stress Management, 12(1), 43-61. https://doi.org/10.1037/1072-5245.12.1.43

Pillinger, J. (2001). Work-Life Balance: Towards a new politics of work and time'. Paper given at the Industrial Law Society Annual Conference, 16th September 2001.

Robbins, S. P. (2004). Organizational Behavior (10th ed.). New Delhi: Prentice Hall of India, Pvt. Ltd.

Ruikar, S. K., \& Abhyankar, S. C. (2015). Perceived Social Support As A Predictor Of Work-Life 
Enrichment. Annamalai International Journal of Business Studies \& Research.

Sekaran, D. (2005). A general guide to writing research proposal and report: A handbook for beginning research. Kisumu: Options Printers and Publishers.

Smith, P. C., Kendall, L. M., \& Hulin, C. L. (1969). Measurement of satisfaction in work and retirement. Chicago, IL: Rand McNally.

Spagnoli, P., Caetano, A., \& Santos, S. C. (2012). Satisfaction with job aspects: Do patterns change over time? Journal of business research, 65(5), 609-616. https://doi.org/10.1016/j.jbusres.2011.02.048

Spector, P. E. (1985). Measurement of human service staff satisfaction: Development of the Job Satisfaction Survey. American journal of community psychology, 13(6), 693-713. https://doi.org/10.1007/BF00929796

Stone, W. H. (2005). Intermediate linkages in the relationship between job satisfaction and employee turnover, Journal of applied psychology, 62(2), 237. https://doi.org/10.1037/0021-9010.62.2.237

Susi, S, J. (2010). Work-Life Balance: The key driver of employee engagement. Asian journal of management research, 1, 1-10.

Thomas, L. T., \& Ganster, D. C. (1995). Impact of family-supportive work variables on work-family conflict and strain: A control perspective. Journal of applied psychology, 80(1), 6. https://doi.org/10.1037/0021-9010.80.1.6

U.S. Department of Labor 2013. Fair Labor Standards Act of 1938. Retrieved from www.dol.gov/oasam/programs/history/flsa1938.htm

Varatharaj, V., \& Vasantha, S. (2012). Work Life Balances A Source of Job Satisfaction - An Exploratory Study on The View of Women Employees in The Service Sector. International Journal of Multidisciplinary Sciences and Engineering, 5(6).

Wanous, J. P., Reichers, A. E., \& Hudy, M. J. (1997). Overall job satisfaction: how good are single-item measures? Journal of applied Psychology, 82(2), 247. https://doi.org/10.1037/0021-9010.82.2.247

Weiss, D. J., Dawis, R. V., \& England, G. W. (1967). Manual for the Minnesota satisfaction questionnaire. Minnesota studies in vocational rehabilitation. https://doi.org/10.1037/t05540-000

Weiss, H. M. (2002). Deconstructing job satisfaction: Separating evaluations, beliefs and affective experiences. Human resource management review, 12(2), 173-194. https://doi.org/10.1016/S1053-4822(02)00045-1

Yadav, R. K., \& Dabhade, N. (2014). Work life balance and job satisfaction among the working women of banking and education sector-A comparative study. International Letters of Social and Humanistic Sciences, 21, 181-201. https://doi.org/10.18052/www.scipress.com/ILSHS.21.181

\section{Copyrights}

Copyright for this article is retained by the author(s), with first publication rights granted to the journal.

This is an open-access article distributed under the terms and conditions of the Creative Commons Attribution license (http://creativecommons.org/licenses/by/4.0/). 